August 2009

\title{
Genocide Prevention and International Law
}

Martin Mennecke

Follow this and additional works at: https://digitalcommons.usf.edu/gsp

\section{Recommended Citation}

Mennecke, Martin (2009) "Genocide Prevention and International Law," Genocide Studies and Prevention: An International Journal: Vol. 4: Iss. 2: Article 7.

Available at: https://digitalcommons.usf.edu/gsp/vol4/iss2/7

This Articles is brought to you for free and open access by the Open Access Journals at Digital Commons @ University of South Florida. It has been accepted for inclusion in Genocide Studies and Prevention: An International Journal by an authorized editor of Digital Commons @ University of South Florida. For more information, please contact digitalcommons@usf.edu. 


\title{
Genocide Prevention and International Law
}

\author{
Martin Mennecke \\ Robert Griffith Visiting Professor, Washington and Lee University
}

The recently published report Preventing Genocide: A Blueprint for U.S. Policymakers (the Albright-Cohen Report) is a welcome addition to the growing efforts to realize the often invoked promise, "Never again."1 In fact, it constitutes the first attempt to translate the existing research on genocide prevention into a policy guide for decision makers, and it deserves praise for taking this step. In particular, from a European perspective, one would hope that institutions and actors such as the Imperial War Museum in London, the International Task Force for Holocaust Education, Research and Remembrance, and the Stiftung für Wissenschaft und Politik in Berlin will engage in similar work to add new perspectives and inspire European leaders.

Being the first of its kind, the Albright-Cohen Report invites a number of criticisms. This cannot come as a surprise, and it may, indeed, help to generate further debate and reflection. My focus here will be on the relationship between genocide prevention and international law. From a legal perspective, there are numerous obvious links between the two-of course, one might say, given that the crime of genocide is defined in a legal instrument, the UN Convention on the Prevention and Punishment of the Crime of Genocide (UNCG). Nonetheless, the treatment of international law in the report remains inconsistent and insufficient. Most often, law is reduced to "international political challenges" (75; emphasis added) or is accorded even less importance. This approach corresponds well with the state of art in the field of genocide studies, where much ink is still spilled on criticizing the alleged and real shortcomings of the legal definition instead of scrutinizing newer developments. The Albright-Cohen Report should have done better and explored how recent trends in international law could contribute and shape future policies in the field of genocide prevention.

\section{The Albright-Cohen Report and International Law}

On a number of occasions the report does touch on the interplay between genocide prevention and international law. Chapter six is in fact titled "International Action: Strengthening Norms and Institutions," and references are made to legal concepts such as the responsibility to protect (xxi) and to institutions such as the International Criminal Court (101ff). ${ }^{2}$ Some of the recommendations set forth are very agreeable, ${ }^{3}$ while others seem totally unrealistic; ${ }^{4}$ overall, there is little self-critical assessment of past US policies vis-à-vis international law. ${ }^{5}$ What is more, legal tools appear to be relegated to a secondary category, appended to and dependent on political considerations. An example of this approach occurs in the brief discussion of the potential need to initiate military operations when no UN authorization can be obtained. On the one hand, the report slurs over the fact that the use of force is generally prohibited under international law (97). ${ }^{6}$ On the other hand, it ignores the fact that the United States has no official policy supporting the existence of a right to humanitarian intervention. ${ }^{7}$

Martin Mennecke, "Genocide Prevention and International Law." Genocide Studies and Prevention 4, 2 (August 2009): 167-175. (C) 2009 Genocide Studies and Prevention. doi:10.3138/gsp.4.2.167 
In what follows I shall highlight some of the report's shortcomings vis-à-vis international law and point to one particular and major omission: the failure to address the legal duty of the United States to prevent genocide.

\section{(a) The Legal Definition of Genocide as "Definitional Trap" for Genocide Prevention}

The Albright-Cohen Report begins by discussing the scope of genocide prevention, calling this "Defining the Challenge." Should prevention focus on genocide alone, or should it also address crimes against humanity and other massive violations of human rights? Does genocide prevention depend on a determination of genocide? The task force behind the report defines the scope of the Blueprint "as the prevention of genocide and mass atrocities, meaning large-scale and deliberate attacks on civilians" (xxi). A number of recent developments, such as the mandate of the UN's Special Adviser on the Prevention of Genocide, the scope of the responsibility to protect, and the newly discovered legal duty to prevent genocide, all point in this same direction. While lawyers were the first to call genocide the "crime of crimes," moved beyond the notion of a hierarchy of suffering. Today, there is a growing readiness to view genocide together with other international crimes-and not only in terms of prevention. A very pertinent proposal has been made by David Scheffer, who for the purposes of prevention, suggests speaking of "atrocity crimes," precisely to avoid the "definitional traps" to which the Albright-Cohen Report refers. ${ }^{9}$ The atrocity crimes terminology allows us to focus the debate on how to respond to a given crisis instead of spending time and energy discussing whether or not the strict requirements of the legal definition of genocide have been met.

Although the report does not mention Scheffer's work, ${ }^{10}$ it includes a similar proposal, explaining that the authors' "central purpose... [is] prevention" and that they advocate "the adoption of measures before acts of massive violence have been committed or labeled" (xxii). This makes a lot of sense. If the objective is to prevent genocide from happening, international efforts must logically be comprehensive, broader than the narrow notion of genocide, in order to prevent just that. Ideally, prevention measures will keep a situation from escalating into genocidal violence so that there will be no genocide. For this reason, any effective genocide-prevention policy also needs to combat crimes against humanity and other grave violations of human rights that could progress to genocide. The term "genocide" is often invoked by activists or the media in the belief that only this particular crime will engage the broader public and lead to a decisive response. The increased level of international interest in the Darfur crisis following the invocation of the term "genocide" seems to confirm the power of the "G-word"; at the same time, however, this situation also shows the term's inherent dangers. There continues to be disagreement about the appropriateness of labeling Darfur a genocide, as well as problems in some quarters with realizing that, even in a case of genocide, the situation on the ground may be more difficult than a fight between "good" and "evil." "Genocide," in its simplified public usage, often seems to blur observers' ability to analyze and understand the relevant conflict.

It therefore comes as a surprise when the authors make a 180-degree turn, announcing that the report will "use the term genocide as a shorthand expression for [a] wider category of crimes" (xxii). This is boldly inconsistent and cannot convince. The same report warns that "legalistic arguments [as to whether or not a certain crisis fulfills the legal definition of genocide] have repeatedly impeded timely and effective action" (xxi)-yet still opts to use the term "genocide." It is deplorable that the 
Albright-Cohen Report, instead of sustaining its own arguments, falls for what it calls the "unmatched rhetorical power" of the term "genocide" (xxi). ${ }^{11}$ A comprehensive approach, addressing all atrocity crimes, could put an end to lengthy and tiring debates over whether or not certain crimes-for example, those committed in the Darfur region-constitute genocide. Such a policy would be more effective than current efforts and would eventually also help to establish an understanding that, "depending upon the circumstances, such international offences as crimes against humanity and large scale war crimes may be no less serious and heinous than genocide." ${ }^{2}$

\section{(b) Impunity as Obstacle to Genocide Prevention-or as Bargaining Chip?}

The question of accountability for genocide and other crimes against humanity is another area of concern addressed in the Albright-Cohen Report. But on this point, too, the report seriously lacks consistency and coherence. At the outset, in a section titled "Early Prevention: Engaging Before the Crisis," the report states that impunity is a serious challenge to genocide prevention (46). Indeed, where there is no accountability for violations of human rights, criminal policies can more easily be implemented. Without the rule of law to distinguish right from wrong, no individual perpetrator will worry about the prospect of future trials. The significant detrimental effect of impunity is a standard feature of the literature on genocide prevention and is stressed by both genocide scholars and inter-governmental organizations. Moreover, it seems increasingly realistic to view the prospect of prosecutions before an international tribunal as potentially deterring future mass atrocities. While this once was a far-fetched scenario, the growing number of international tribunals, the existence of a permanent International Criminal Court, and the supplementary use of national prosecutions in third states (under the title of "universal jurisdiction"-a concept that is omitted from the report) do seem to have an impact on the ground. ${ }^{13}$ Thus, the report is right to assert that "threatening legal and moral accountability for violations of international law ... signals potentially serious repercussions for inexcusable behavior" (43).

In this context, it is important to acknowledge and consider that this threat of prosecution as means of prevention can prove very costly. Only briefly mentioned in the report, this fact is starkly illustrated by the response of Sudan's President Al-Bashir to the ICC's arrest warrant. Is justice to be pursued even if it means that the conflict will be prolonged and that more people will die? Who is to make that decision? Proponents of international criminal justice must face these questions and must be prepared to deal with the unintended consequences of ICC investigations. The report claims that

responsible members of the international community, including the United States, have concluded that the potential benefits do indeed outweigh the costs, and they are unlikely again to allow disputes over the means of pursuing justice to overwhelm the principle that justice must be done. (103).

This assessment is overly optimistic. The ongoing debates surrounding the Bashir case before the ICC illustrate that there is no such agreement yet, not even among "responsible" Western states or among ICC member states.

The report also lacks consistency with respect to fighting impunity, readily proposing in a separate section that accountability be used as a bargaining chip. Discussing policy options and "Tools Available to the United States to Help Halt and Reverse Escalating Threats of Genocide and Mass Atrocities," the report lists offering amnesties and immunities among these tools (60ff, Table 1$)^{14}$. This idea is obviously irreconcilable with earlier statements in the report. Moreover, in trying to devise 
a policy on genocide prevention, it would have been better to shift the emphasis from what combating impunity means for an ongoing conflict and what it means for future conflicts and for potential perpetrators. If amnesties remain an "available tool," even within the context of genocide prevention, then potential génocidaires need not fear prosecution before the ICC or elsewhere. ${ }^{15}$ Furthermore, and equally importantly, it seems very questionable whether amnesties and immunities still are "available tools" vis-à-vis crimes against humanity such as genocide. It seems to be generally accepted that international tribunals, at least, are not bound by national amnesties and immunities; indeed, there is significant practice suggesting that contemporary international law prohibits outright amnesties for crimes against humanity and genocide. Is the Albright-Cohen Report suggesting that the United States place itself outside this trend?

\section{(c) The Responsibility to Protect}

Several times throughout the report the authors refer to the notion of a responsibility to protect (R2P). The most interesting contribution appears in chapter five, "Employing Military Options," which makes a convincing case that the US government (as well as many other actors) needs to translate R2P into concrete guidance for military training and operations (73ff). Beyond that, however, the authors add little to the existing literature. Indeed, the Albright-Cohen Report displays some difficulties in properly situating $\mathrm{R} 2 \mathrm{P}$ in the context of genocide prevention. For example, the report suggests that $\mathrm{R} 2 \mathrm{P}$ "provide[s] the legitimate basis for overriding national sovereignty" (58) ${ }^{16}$ - a serious misreading of what R2P is about, suited only to confirm concerns among readers from developing countries that R2P could serve as a standing excuse for US interventions. R2P is a significant departure from the traditional notion of sovereignty as an impermeable iron wall, protecting murderous regimes-instead of their people-from outside interference. At the same time, R2P confirms sovereignty and is conceived as its "ally, not [its] adversary." 17 Thus, it would be more appropriate to explore how $\mathrm{R} 2 \mathrm{P}$ can contribute to efforts to prevent atrocity crimes, instead of deliberating (belated) military interventions.

The report's only concrete recommendation on $\mathrm{R} 2 \mathrm{P}$ is that the new US administration should reaffirm the commitment of the United States to this concept. R2P has indeed become a buzzword at the United Nations, and it deserves close attention. Adopted at the UN World Summit of heads of state in 2005, R2P was meant to go beyond the old debates on the legality of armed ("humanitarian") interventions into internal conflicts and massive human-rights violations without UN authorization. According to the doctrine of R2P, state sovereignty confers on a government a responsibility to protect its people from genocide, war crimes, ethnic cleansing, and crimes against humanity; other states and the international community have a responsibility to support the government in this undertaking. If a state "manifestly" fails in its responsibility, "the international community...[is] prepared to take collective action, in a timely and decisive manner, through the Security Council, in accordance with the [UN] Charter," to protect the affected people. ${ }^{18}$ R2P is thus not simply a remake of the older idea of "humanitarian intervention" but a new, comprehensive norm that builds and expands on the classic understanding of sovereignty and obliges both individual states and the international community as a whole to prevent, react, and rebuild. R2P is not yet binding law but is often described as "evolving" in that direction. Be that as it may, R2P was introduced on a broad basis 
of international support, adopted at the highest level and in consensus by the UN General Assembly, and later reaffirmed by the UN Security Council. ${ }^{19}$

The Albright-Cohen Report calls R2P the "potentially most important normative addition" since the drafting of the UNCG-but does not translate this into concrete policies, instead reducing R2P to a tool of "moral suasion" (98). While the Darfur crisis and the enduring inability of the international community to fundamentally change the situation on the ground pose extreme challenges to R2P, there is also good news-which reinforces the need for this report, and any future genocide-prevention policy, to engage with R2P. For example, R2P was successfully invoked by former UN secretary-general Kofi Annan and others in mediating the post-election crisis in Kenya early in 2008. ${ }^{20}$ In July 2009, UN member states will discuss how to implement R2P in the UN General Assembly, on the basis of a comprehensive report by the UN secretary-general (published on 12 January 2009, after publication of the Albright-Cohen Report) that presents first suggestions on how to operationalize $\mathrm{R}^{\mathrm{P}} .^{21}$

\section{(d) The Legal Duty to Prevent Genocide}

If we have so far focused on areas in which the report's treatment of international legal matters is insufficient or inconsistent, we now turn to an issue that is omitted completely. On 26 February 2007, the International Court of Justice (ICJ)—the highest judicial organ of the United Nations, which hears disputes between states and does not deal with the criminal responsibility of individuals-rendered a judgment in a case between Bosnia-Herzegovina and Serbia. Bosnia had asked the Court to rule that Serbia had violated the UNCG, and the judges did indeed find that this was the case; the Court specified, however, that Serbia was not, in a legal sense, responsible for the genocidal massacre committed at Srebrenica in July 1995. Instead, the Court ruled that Serbia had violated two legal duties enshrined in the UNCG: first, the duty to punish génocidaires present on its territory, and, second and independently, the duty to prevent genocide-outside its own territory. ${ }^{22}$

This legal duty to prevent genocide is, of course, directly relevant to the matter discussed in the Albright-Cohen Report. After decades of protracted debates, the United States ratified the UNCG in 1988 and is thus bound by this duty. ${ }^{23}$ To start with, this duty could - and, indeed, should - serve as one reason for the United States to formulate a policy on genocide prevention: it is, as a matter of law, legally obliged to prevent genocide. This is important, as the US government has been very reluctant to accept such duties in the past. In spring 1994, for example, the US government meticulously avoided calling the massive crimes committed in Rwanda by their rightful name (i.e., genocide); legal experts within the State Department warned the administration to "be careful" because calling it genocide "could commit the US [government] to actually do something." 24 This reluctance again became evident in how the aforementioned R2P doctrine at the UN World Summit in $2005 .^{25}$ It is a glaring omission that this new development in international law is not even mentioned, let alone discussed, in the Genocide Prevention Task Force's report. ${ }^{26}$

The ICJ found the legal duty to prevent genocide established under the very first provision of the UNCG. ${ }^{27}$ Article 1 reads, "The Contracting Parties confirm that genocide, whether committed in time of peace or in time of war, is a crime under international law which they undertake to prevent and to punish." ${ }^{28}$ While this may seem to the layperson the most natural, perhaps even self-evident, reading of an international treaty through which states aim to prevent and punish genocide, this 
part of the ruling did come as a surprise to international lawyers: prior to the ICJ's judgment, few had read a legal duty to prevent genocide as existing under the UNCG. Most believed that art. 1 entailed only a programmatic statement, not a legal duty. ${ }^{29}$ In the context of formulating a policy on genocide prevention, therefore, this newly stated duty is of course an interesting development. What exactly is the scope of this obligation, and what does it mean for the US government?

The Court's judgment addresses these questions and formulates some conditions to help measure whether states comply with the duty to prevent genocide. Importantly, the Court decided that the "the obligation in question is one of conduct and not one of result, in the sense that a State cannot be under an obligation to succeed, whatever the circumstances, in preventing the commission of genocide." ${ }^{30}$ There is little room for excuses, however, as states are expected "to employ all means reasonably available to them, so as to prevent genocide so far as possible"; in fact, it is "irrelevant whether the State whose responsibility is in issue claims, or even proves, that even if it had employed all means reasonably at its disposal, they would not have sufficed to prevent the commission of genocide." 31 Accordingly, a state incurs legal responsibility for violating the UNCG "if the State manifestly failed to take all measures to prevent genocide which were within its power, and which might have contributed to preventing the genocide." 32 The ICJ acknowledges that different states may have different capacities to prevent genocide from being committed; the scope of the duty therefore depends on factors such as geographic proximity and political influence. Any measure taken to prevent genocide must comply with general international law (which, for example, makes the unilateral use of force-often discussed as "humanitarian interventions"-very questionable). Finally, the Court addresses the issue of when this legal duty applies. Calling it "absurd" in the context of prevention to wait until genocide has been committed and determined to fit the legal definition, the ICJ's judgment holds that "a State's obligation to prevent, and the corresponding duty to act, arise at the instant that the State learns of, or should normally have learned of, the existence of a serious risk that genocide will be committed." 33 Thus, the "definitional traps" referred to in the Albright-Cohen Report should not stop states in their endeavors: the question is not whether a certain crisis constitutes genocide but whether it could evolve into genocide. There is a link and potential overlap between the duty to prevent genocide and the responsibility to protect.

Even though judgments of the ICJ are legally binding only on the parties to the case in question, it is clear that all other parties to the UNCG are under the same obligation. What about the United States, then? On 9 September 2004, Colin Powell, then US secretary of state, informed the Senate Foreign Relations Committee of the results of the Atrocities Documentation Project, stating that "genocide has been committed" in Darfur. ${ }^{34}$ This was a significant shift away from the attitude prevalent in 1994, when the "G-word" was avoided at all costs-but was Powell correct in claiming that "we have been doing everything we can to get the Sudanese Government to act responsibly"? Was, and is, the United States meeting the requirements set forth by the ICJ? What about other parties to the UNCG, such as China, Russia, and South Africa? Does not a particular responsibility rest with the permanent members of the UN Security Council, both because of their special status and because of their actual influence on Sudan? These are questions genocide scholars as well as anti-genocide activists need to explore. The Albright-Cohen Report's failure to undertake the first steps toward operationalizing this duty as it applies to the United States is a major shortcoming. 


\section{Concluding Observations}

The Albright-Cohen Report sets out to "enable the United States to take preventive action, together with international partners, to forestall the specter of future cases of genocide and mass atrocities" (ix). In terms of incorporating and making use of international law in this task, the report has a number of shortcomings. Nonetheless, the authors and institutions behind the report deserve credit for engaging with this important topic and for putting it on the agenda. It is to be hoped that the institutions involved in authoring the report will succeed in bringing this matter to the attention of the new US administration. Moreover, it would seem advisable to follow up on the report; there could, for example, be an annual genocide-prevention report to review ongoing policies and make recommendations for the future. As the UN secretarygeneral recently stated, "We can, and must, do better."35

\section{Notes}

1. Madeleine K. Albright and William S. Cohen, chairs, Preventing Genocide: A Blueprint for U.S. Policymakers (Washington, DC: Genocide Prevention Task Force, 2008),

http://www.usip.org/genocide_taskforce/report.html (accessed 11 June 2009). Subsequent references appear parenthetically in the text.

2. See also the Executive Summary (xvii): "To prevent genocide, our government must draw on a wide array of analytical, diplomatic, economic, legal, and military instruments and engage a variety of partners" (emphasis added).

3. E.g., the suggestion to re-engage with the UN Human Rights Council (107ff). Despite all its flaws and misuse, the Human Rights Council, with its new Universal Periodic Review mechanism, may provide a welcome opportunity to introduce an annual review of genocideprevention measures adopted by individual states.

4. E.g., the suggestion that the five permanent members of the UN Security Council should resolve that "unless three permanent members were to agree to veto a given resolution [concerning genocide prevention], all five would abstain or support it" (106). Given that the United States, together with the United Kingdom and France, could always block the other two permanent members (and not the other way around), it is not clear why China and Russia should agree to such a proposal.

5. See, e.g., the treatment of the ICC (101ff). The report states that the United States has not become a party to the ICC but continues to be committed to international justice; the authors choose not to mention either the fact that the United States still cannot envisage its own officials' ever being submitted to international scrutiny or the hostile anti-ICC policy adopted by the first Bush administration. Similarly, the report's discussion of the Darfur referral by the UN Security Council does not mention the United States' strong initial opposition, which led to some highly questionable compromises in the relevant Security Council resolution (Resolution No. 1593 of 31 March 2005). For example, the costs of the ICC's investigations in Darfur will be borne not by the United Nations (at whose request the ICC is addressing the Darfur situation) but by ICC member states.

6. The reference in the report to an allegedly growing practice by regional organizations of using force without prior authorization from the UN Security Council is unsubstantiated and seems very questionable. A closer examination of relevant operations suggests that the African Union as well as other actors confirm the significance of the UN resolutions. See Christine Gray, International Law and the Use of Force, 3rd ed. (Oxford: Oxford University Press, 2008), 370ff.

7. "Authority of the President under Domestic and International Law to Use Military Force Against Iraq" (Memorandum Opinion for Counsel to the President, 23 October 2002), 17.

8. Prosecutor v. Kambanda, Judgment and Sentence, ICTR-97-23-S (4 September 1998), para. 16. 
9. Scheffer has written extensively on the notion of atrocity law. See David Scheffer, "Genocide and Atrocity Crimes," Genocide Studies and Prevention 1 (2006): 229-50; on this topic see also Martin Mennecke, "What's In a Name? Reflections on Using, Not Using, and Overusing the 'G-Word,'” Genocide Studies and Prevention 2 (2007): 57-71.

10. Interestingly, however, Scheffer is listed as an expert consultant to the task force (128).

11. This inconsistency permeates the entire report; for example, the authors suggest the establishment of an Atrocities Prevention Committee within the US administration (xviii).

12. Report of the International Commission of Inquiry on Darfur to the United Nations Secretary General, UN Doc. S/2005/60 (25 January 2005), para. 522 (original emphasis).

13. On the notion of prevention through prosecutions see generally Martin Mennecke, "Punishing Genocidaires: A Deterrent Effect or Not?" Human Rights Review 8 (2007): 319-39.

14. See also page 70: "[A]lthough it is likely to be distasteful and morally hazardous, policymakers should not dismiss the potential benefits of rewarding 'bad people' for 'good behavior.'" Yet again, there is no mention of international law rules that regulate and ultimately prohibit certain rewards.

15. The report also notes that deterrence will be more effective if "the international community demonstrates its willingness to detain indicted fugitives and bring them before the court" (103).

16. On the topic of R2P, it seems particularly evident that the report draws on the work of several different expert groups; compare, for example, the much more accurate and cautious treatment on page 98 .

17. UN Secretary-General, Implementing the Responsibility to Protect, UN Doc. A/63/677 (12 January 2009), para. 10a.

18. World Summit Outcome Document, UN Doc. A/60/1 (24 October 2005), paras. 138-9. The $\mathrm{UN}$ version of R2P builds on earlier work by the International Commission on Intervention and State Sovereignty (ICISS), a group of experts commissioned by the government of Canada. The ICISS report proposed a more far-reaching version of R2P; some have therefore called the UN version "R2P lite": see Alex J. Bellamy, Responsibility to Protect: The Global Effort to End Mass Atrocities (Cambridge: Polity Press, 2009), 67.

19. UN Security Council Resolution 1674 (28 April 2006). The Albright-Cohen Report also refers to the "breadth of global consensus," which is "critical" and "represents a strong foundation for intergovernmental co-operation to prevent genocide and mass atrocities" (5).

20. See Roger Cohen, "How Kofi Annan Rescued Kenya," New York Review of Books, 14 August 2008.

21. UN Secretary-General, Implementing $R 2 P$.

22. Application of the Convention on the Prevention and Punishment of the Crime of Genocide (Bosnia and Herzegovina v. Serbia and Montenegro), Judgment, 26 February 2007, http://www.icj-cij.org/docket/index.php?p1=3\&k=8d\&p3=4\&case=91 (accessed 12 June 2009) [Bosnia v. Serbia]. On the duty to prevent genocide, see generally William A. Schabas, Genocide in International Law: The Crime of Crimes, 2nd ed. (Cambridge: Cambridge University Press, 2009), 520ff.

23. On the complicated relationship between the United States and the crime of genocide see Lawrence J. LeBlanc, The United States and the Genocide Convention (Durham, NC: Duke University Press, 1991).

24. Office of the Deputy Assistant Secretary of Defence for Middle East/Africa Region, Department of Defence, Discussion Paper (1 May 1994). For an instructive analysis of the approach taken by the Clinton administration see Samantha Power, "A Problem from Hell": America and the Age of Genocide (New York: Basic Books, 2002), 329ff.

25. See, e.g., the letter from the US representative to the United Nations, John Bolton, on 30 August 2005: "we would make changes to make clear that the obligation/responsibility 
[of the international community and the Security Council] discussed in the text is not of a legal [but a moral] character."

26. The authors of the Albright-Cohen Report seem wholly unaware of this duty. On page 94, for example, it is suggested that the UNCG embodies "aspirations" rather than legal obligations. It should be noted that this criticism also can be leveled against the field of genocide studies. Since the ICJ issued its judgment in Bosnia v. Serbia, only one relevant article (William Schabas, "Genocide and the International Court of Justice: Finally, a Duty to Prevent the Crime of Crimes," Genocide Studies and Prevention 2 (2007): 101-22) has appeared in any of the journals focusing on genocide studies. The judgment is of interest to genocide studies not only because of the duty to prevent genocide but also for its finding that only the massacres committed at Srebrenica met the criteria of the legal definition of genocide. Most genocide scholars continue to list Bosnia as a whole among recent cases of genocide, without engaging with this recent ruling by the UN's highest judicial organ. At the same time, the Court's judgment has been heavily criticized for finding that Serbia did not exercise sufficient control over the Bosnian Serbs to be attributed direct responsibility for Srebrenica. It would be beneficial to the debate among international lawyers for genocide scholars to add their insights on this important question.

27. See Bosnia v. Serbia, Judgment, paras. 425-32.

28. Convention on the Prevention and Punishment of the Crime of Genocide, 9 December 1948, 78 U.N.T.S. 277, http://www.unhchr.ch/html/menu3/b/p_genoci.htm (accessed 12 June 2009), art. 1.

29. For an early publication arguing for the existence of legal duty see Stephen J. Toope, "Does International Law Impose a Duty upon the United Nations to Prevent Genocide?" McGill Law Journal 46 (2000): 187-94.

30. Bosnia v. Serbia, Judgment, para. 430.

31. Ibid.

32. Ibid.

33. Ibid., para. 431.

34. Colin L. Powell, "The Crisis in Darfur" (written remarks before the Senate Foreign Relations Committee, 9 September 2004), http://2001-2009.state.gov/secretary/former/ powell/remarks/36042.htm (accessed 12 June 2009).

35. UN Secretary-General, Implementing R2P, para. 6 . 